www.mdpi.com/journal/marinedrugs

Article

\title{
Cytotoxic and Antibacterial Angucycline- and Prodigiosin- Analogues from the Deep-Sea Derived Streptomyces sp. SCSIO 11594
}

\author{
Yongxiang Song ${ }^{1, \dagger}$, Guangfu Liu ${ }^{2, \dagger}$, Jie Li ${ }^{1}$, Hongbo Huang ${ }^{1}$, Xing Zhang ${ }^{1}$, Hua Zhang ${ }^{2, *}$ \\ and Jianhua $\mathrm{Ju}^{1, *}$
}

1 CAS Key Laboratory of Tropical Marine Bio-resources and Ecology, Guangdong Key Laboratory of Marine Materia Medica, RNAM Center for Marine Microbiology, South China Sea Institute of Oceanology, Chinese Academy of Sciences, 164 West Xingang Road, Guangzhou 510301, China; E-Mails: songx@scsio.ac.cn (Y.S.); lijietaren@yeah.net (J.L.); huanghb@scsio.ac.cn (H.H.); beishidazhangxing@163.com (X.Z.)

2 Department of Clinical Biochemistry, Institute of Clinical Laboratory Medicine, Guangdong Provincial Key Laboratory of Medical Molecular Diagnostics, Guangdong Medical College, No. 1 Xincheng Road, Dongguan 523808, China; E-Mail: 454143108@qq.com

$\dagger$ These authors contributed equally to this work.

* Authors to whom correspondence should be addressed; E-Mails: zhanghuahh11@126.com (H.Z.); jju@scsio.ac.cn (J.J.); Tel.: +769-2289-6379 (H.Z.); +86-020-8902-3028 (J.J.);

Fax: +769-2289-0682 (H.Z.); +86-020-8902-3028 (J.J.).

Academic Editors: Sergey A. Dyshlovoy and Friedemann Honecker

Received: 17 January 2015 / Accepted: 17 February 2015 / Published: 16 March 2015

Abstract: Two new C-glycoside angucyclines, marangucycline A (1) and marangucycline B (2), along with three known compounds, dehydroxyaquayamycin (3), undecylprodigiosin (4) and metacycloprodigiosin (5), have been identified as products of the deep-sea sediment strain Streptomyces sp. SCSIO 11594. New structures were elucidated on the basis of HRESIMS, 1D and 2D NMR analyses and comparisons to previously reported datasets. Compounds 2 and $\mathbf{4}$ displayed in vitro cytotoxicity against four cancer cell lines A594, CNE2, HepG2, MCF-7 superior to those obtained with cisplatin, the positive control. Notably, compound $\mathbf{2}$ bearing a keto-sugar displayed significant cytotoxicity against cancer cell lines with $\mathrm{IC}_{50}$ values ranging from 0.24 to $0.56 \mu \mathrm{M}$; An $\mathrm{IC}_{50}$ value of $3.67 \mu \mathrm{M}$ was found when using non-cancerous hepatic cell line HL7702, demonstrating the cancer cell selectivity of $\mathbf{2}$. Compounds $\mathbf{1}-\mathbf{3}$ were proved to have weak antibacterial activities against 
Enterococcus faecalis ATCC29212 with an MIC value of $64.0 \mu \mathrm{g} / \mathrm{mL}$. Moreover, 3 displayed selective antibacterial activity against methicillin-resistant Staphylococcus epidermidis shhs-E1 with an MIC value of $16.0 \mu \mathrm{g} / \mathrm{mL}$.

Keywords: cytotoxicity; antibacterial; marangucyclines; deep-sea; Streptomyces sp. SCSIO 11594

\section{Introduction}

Reports of increasing incidences of various cancers and the rise of multidrug resistant bacteria have inspired and renewed interest in the discovery of new secondary metabolites from marine-derived microorganisms as new drugs or new drug leads [1-3]. Deep-sea derived microorganisms, by virtue of their extreme living environments and selective pressures to which they have adapted, are considered especially exciting as potentially rich sources of new agents for drug discovery [4,5]. Historically speaking, terrestrial actinomycetes have been instrumental in the discovery of important secondary metabolites including antibiotics, antitumor agents, immunosuppressive agents and enzyme inhibitors [6]. This role of "discovery catalyst" is now gradually shifting to marine-derived actinomyces due to diminishing rates of new compound discovery and increasingly frequent "rediscovery" of known agents from terrestrial actinomyces [7-9]. Our continuing studies of cytotoxic and antibacterial compounds from marine-derived actinomyces, especially from the deep-sea derived strains, have led to the discoveries of antibacterial and cytotoxic cyclic peptide marthiapeptide A [10], antimalarial marinacarbolines and indolactam alkaloids [11] from deep-sea derived Marinactinospora thermotolerans SCSIO 00652, cytotoxic and antibacterial marfuraquinocins and phenaziterpenes from a deep-sea sediment actinomycete Streptomyces niveus SCSIO 3406, antibacterial cyclic peptides desotamides and marformycins from the deep-sea sediment actinomycetes Streptomyces scopuliridis SCSIO ZJ46 [12] and Streptomyces drozdowiczii SCSIO 10141 [13], respectively.

In expanding our efforts to identify cytotoxic and antibacterial secondary metabolites from deep-sea derived actinomycetes, we isolated and identified Streptomycetes sp. strain SCSIO 11594 from a South China Sea sediment at a depth of $2403 \mathrm{~m}$. This strain was found to produce cytotoxic and antibacterial substances warranting more detailed evaluation of these bioactivities. Metabolite analyses and subsequent structure elucidation efforts revealed two new $\mathrm{C}$-glycoside angucyclines, marangucyclines A (1) and B (2), along with three known compounds identified as dehydroxyaquayamycin (3), undecylprodigiosin (4) and metacycloprodigiosin (5), as shown in Figure 1. Herein, we report the isolation, structure elucidation and bioactivity data for 1-5 from Streptomyces sp. SCSIO 11594. 


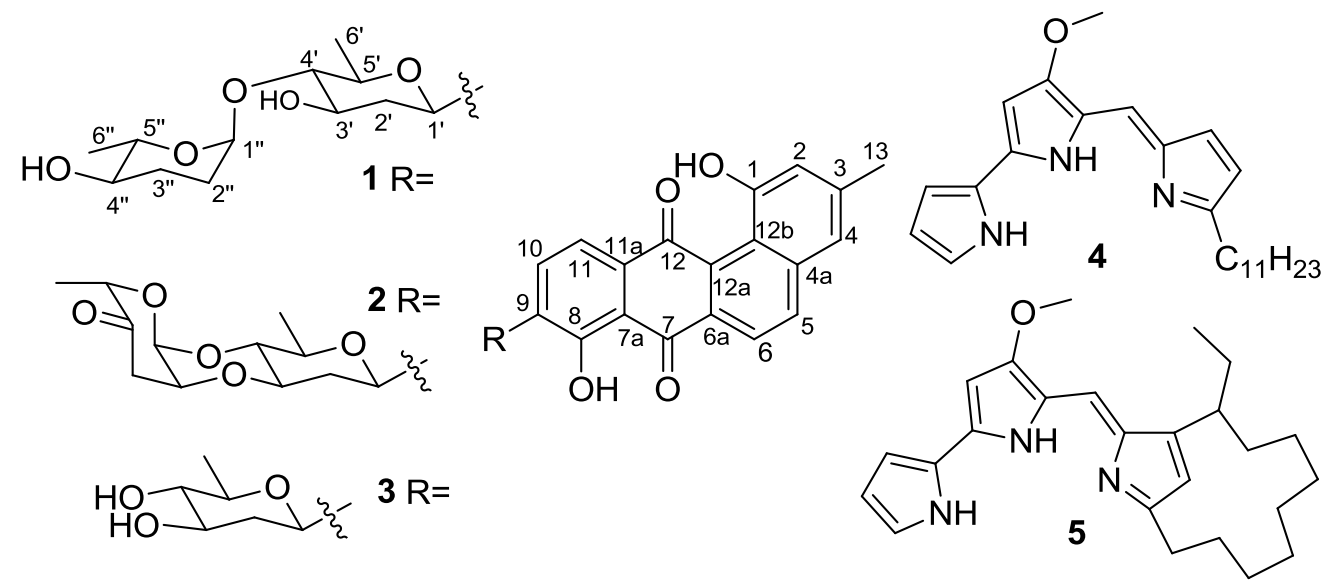

Figure 1. Secondary metabolites 1-5 from Streptomyces sp. SCSIO 11594.

\section{Results and Discussion}

\subsection{Structure Elucidation}

Compound 1, marangucycline A, was isolated as a brown amorphous powder. The UV spectrum showed maxima at 239, 323 and $437 \mathrm{~nm}$, indicating the presence of a large conjugated moiety. The IR spectrum showed characteristic absorptions at 3418 (hydroxyl), 2928 and 2877 (methyl) and $1632 \mathrm{~cm}^{-1}$ (the chelated quinone carbonyl). The compound's molecular formula, $\mathrm{C}_{31} \mathrm{H}_{32} \mathrm{O} 9$, was determined on the basis of the HRESIMS peak at $m / z 571.1946[\mathrm{M}+\mathrm{Na}]^{+}$, requiring 16 degrees of unsaturation. Comprehensive analysis of the ${ }^{1} \mathrm{H}$ and ${ }^{13} \mathrm{C}$ NMR spectroscopic data strongly implied the presence of a typical angucycline of tetrangulol skeleton, with 1,8-dihydroxy-3-methyl-substituted and 9-C-glycosylated [14-17]. Detailed analysis of $1 \mathrm{D}\left({ }^{1} \mathrm{H}\right.$ and $\left.{ }^{13} \mathrm{C}\right)$ and $2 \mathrm{D}$ (COSY, HMQC, HMBC, NOESY) NMR spectra of 1 (Supplementary Information), allowed the complete assignment of spectra signals (Table 1) and elucidation of the structure (Figures 2 and 3 ).

Table 1. ${ }^{1} \mathrm{H}(500 \mathrm{MHz})$ and ${ }^{13} \mathrm{C}$ NMR (125 MHz) spectroscopic data of compounds $\mathbf{1}$ and 2 in $\mathrm{CDCl}_{3}$.

\begin{tabular}{cccccc}
\hline \multirow{2}{*}{ pos. } & \multicolumn{2}{c}{ Marangucycline A (1) } & & \multicolumn{2}{c}{ Marangucycline B (2) } \\
\cline { 2 - 3 } \cline { 5 - 6 } & $\boldsymbol{\delta}_{\mathbf{C}}$ & $\boldsymbol{\delta}_{\mathbf{H},}$ mult. $(\boldsymbol{J}$ in $\mathbf{H z})$ & & $\boldsymbol{\delta}_{\mathbf{C}}$ & $\boldsymbol{\delta}_{\mathbf{H}}$, mult. $(\boldsymbol{J}$ in Hz) \\
\hline 1 & $155.6, \mathrm{C}$ & & $155.3, \mathrm{C}$ & \\
2 & $120.2, \mathrm{CH}$ & $7.12, \mathrm{~s}$ & & $120.2, \mathrm{CH}$ & $7.15, \mathrm{~s}$ \\
3 & $142.1, \mathrm{C}$ & & & $142.1, \mathrm{C}$ & \\
4 & $121.5, \mathrm{CH}$ & $7.23, \mathrm{~s}$ & & $121.3, \mathrm{CH}$ & $7.27, \mathrm{~s}$ \\
$4 \mathrm{a}$ & $132.6, \mathrm{C}$ & & & $132.5, \mathrm{C}$ & \\
5 & $137.7, \mathrm{CH}$ & $8.11, \mathrm{~d}, J=8.5$ & & $137.6, \mathrm{CH}$ & $8.14, \mathrm{~d}, J=8.5$ \\
6 & $122.0, \mathrm{CH}$ & $8.29, \mathrm{~d}, J=8.5$ & & $121.8, \mathrm{CH}$ & $8.32, \mathrm{~d}, J=8.5$ \\
$6 \mathrm{a}$ & $135.0, \mathrm{C}$ & & & $134.8, \mathrm{C}$ & \\
7 & $188.3, \mathrm{C}$ & & $188.3, \mathrm{C}$ & \\
$7 \mathrm{a}$ & $114.2, \mathrm{C}$ & & $114.1, \mathrm{C}$ & \\
\hline
\end{tabular}


Table 1. Cont.

\begin{tabular}{|c|c|c|c|c|}
\hline 8 & $158.2, \mathrm{C}$ & & $157.8, \mathrm{C}$ & \\
\hline 9 & $138.6, \mathrm{C}$ & & $137.7, \mathrm{C}$ & \\
\hline 10 & 133.6, $\mathrm{CH}$ & $7.90, \mathrm{~d}, J=8.0$ & 133.6, CH & $7.92, \mathrm{~d}, J=8.0$ \\
\hline 11 & $121.3, \mathrm{CH}$ & $7.86, \mathrm{~d}, J=8.0$ & $121.2, \mathrm{CH}$ & $7.88, \mathrm{~d}, J=8.0$ \\
\hline $11 \mathrm{a}$ & $133.6, \mathrm{C}$ & & $133.5, \mathrm{C}$ & \\
\hline 12 & 189.6, C & & $189.4, \mathrm{C}$ & \\
\hline $12 \mathrm{a}$ & 139.3, C & & 139.2, C & \\
\hline $12 b$ & $120.2, \mathrm{C}$ & & $120.1, \mathrm{C}$ & \\
\hline 13 & $21.4, \mathrm{CH}_{3}$ & $2.48, \mathrm{~s}$ & $21.3, \mathrm{CH}_{3}$ & $2.50, \mathrm{~s}$ \\
\hline $1-\mathrm{OH}$ & & 11.43, br s & & 11.38, br s \\
\hline $8-\mathrm{OH}$ & & 12.62, br s & & 12.66, br s \\
\hline $1^{\prime}$ & $71.3, \mathrm{CH}$ & $4.90, \mathrm{~d}, J=11.2$ & $71.5, \mathrm{CH}$ & $5.01, \mathrm{~d}, J=11.0$ \\
\hline $2^{\prime}$ & $38.8, \mathrm{CH}_{2}$ & $2.57, \mathrm{~m} ; 1.46, \mathrm{~m}$ & $36.6, \mathrm{CH}_{2}$ & $2.48, \mathrm{~m} ; 1.54, \mathrm{~m}$ \\
\hline $3^{\prime}$ & $71.5, \mathrm{CH}$ & $3.87, \mathrm{~m}$ & $77.1, \mathrm{CH}$ & 3.84, ddd, $J=11.5,9.0,4.5$ \\
\hline $4^{\prime}$ & $89.2, \mathrm{CH}$ & $3.07, \mathrm{t}, J=6.5$ & $74.5, \mathrm{CH}$ & $3.52, \mathrm{t}, J=9.0$ \\
\hline $5^{\prime}$ & 74.7, $\mathrm{CH}$ & $3.57, \mathrm{~m}$ & 74.6, $\mathrm{CH}$ & $3.59, \mathrm{~m}$ \\
\hline $6^{\prime}$ & $18.6, \mathrm{CH}_{3}$ & $1.38, \mathrm{~d}, J=6.0$ & $17.5, \mathrm{CH}_{3}$ & $1.43, \mathrm{~d}, J=6.0$ \\
\hline $1^{\prime \prime}$ & $98.9, \mathrm{CH}$ & 4.92, br s & $91.4, \mathrm{CH}$ & $5.19, \mathrm{~d}, J=3.0$ \\
\hline $2^{\prime \prime}$ & 27.3, $\mathrm{CH}_{2}$ & $1.93, \mathrm{~m} ; 1.83, \mathrm{~m}$ & $71.1, \mathrm{CH}$ & $4.35, \mathrm{q}, 3.0$ \\
\hline $3^{\prime \prime}$ & $30.1, \mathrm{CH}_{2}$ & $1.87, \mathrm{~m} ; 1.25, \mathrm{~m}$ & $39.9, \mathrm{CH}_{2}$ & $2.65, \mathrm{~m}$ \\
\hline $4^{\prime \prime}$ & $71.8, \mathrm{CH}$ & $3.36, \mathrm{td}, J=10.0,4.0$ & 207.7, C & \\
\hline $5^{\prime \prime}$ & $71.7, \mathrm{CH}$ & $3.91, \mathrm{~m}$ & $77.8, \mathrm{CH}$ & $4.75, \mathrm{q}, J=6.5$ \\
\hline $6^{\prime \prime}$ & $18.0, \mathrm{CH}_{3}$ & $1.33, \mathrm{~d}, J=6.0$ & $16.2, \mathrm{CH}_{3}$ & $1.39, \mathrm{~d}, J=6.5$ \\
\hline
\end{tabular}

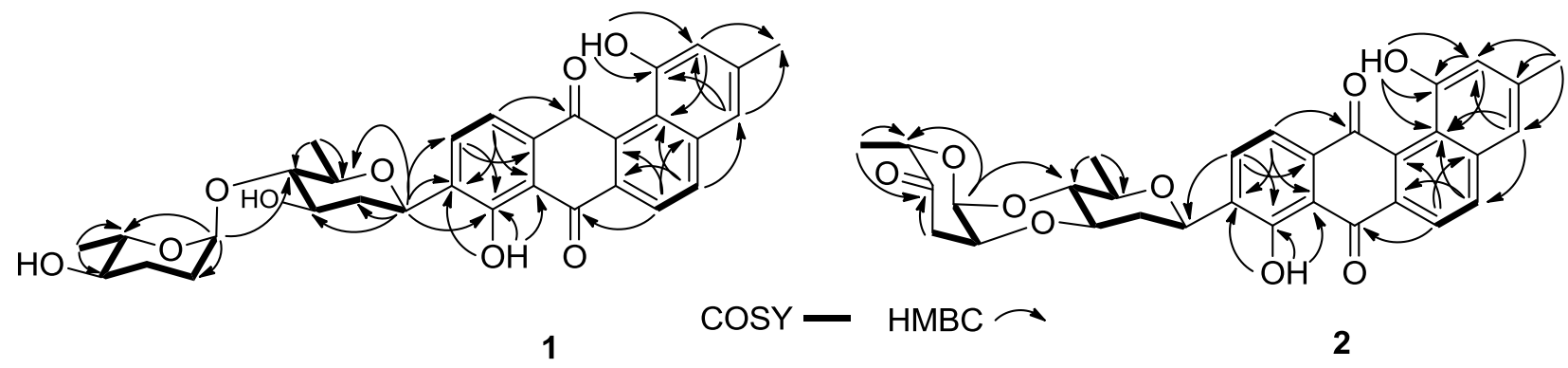

Figure 2. COSY and selected HMBC correlations for compounds $\mathbf{1}$ and $\mathbf{2}$.

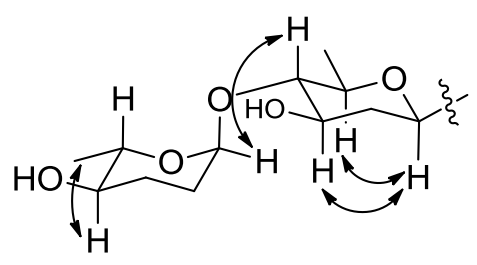

$1 \mathrm{R}$

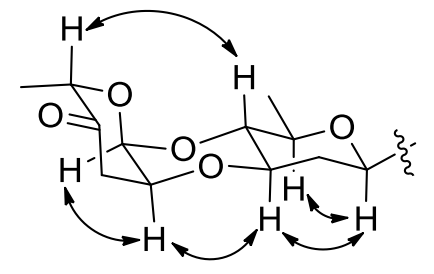

$2 \mathrm{R}$

Figure 3. Selected NOESY correlations for the disaccharide moiety $(R)$ of compounds 1 and 2. 
${ }^{1} \mathrm{H}$ NMR spectra revealed the presence of two intramolecularly H-bonded hydroxyl groups at $\delta_{\mathrm{H}} 12.62$ and 11.43. Two pairs of ortho-coupled aromatic proton signals appeared at $\delta_{\mathrm{H}} 8.29$ (d, $J=8.5 \mathrm{~Hz})$ and $\delta_{\mathrm{H}} 8.11(\mathrm{~d}, J=8.5 \mathrm{~Hz}), \delta_{\mathrm{H}} 7.90(\mathrm{~d}, J=8.5 \mathrm{~Hz})$ and $\delta_{\mathrm{H}} 7.86(\mathrm{~d}, J=8.5 \mathrm{~Hz})$, which also were found at C-6 ( $\left.\delta_{\mathrm{C}} 122.0\right)$ and C-5 ( $\left.\delta_{\mathrm{C}} 137.7\right), \mathrm{C}-10\left(\delta_{\mathrm{C}} 133.6\right)$ and $\mathrm{C}-11\left(\delta_{\mathrm{C}} 121.3\right)$ based on HSQC data. Another two singlet proton signals at $\delta_{\mathrm{H}} 7.23(\mathrm{~s})$ and $\delta_{\mathrm{H}} 7.12(\mathrm{~s})$ were associated with $\mathrm{C}-4$ $\left(\delta_{\mathrm{C}} 121.5\right)$ and $\mathrm{C}-2\left(\delta_{\mathrm{C}} 120.2\right)$, respectively. HMBC correlations from $\delta_{\mathrm{H}} 11.43$ to $\mathrm{C}-1\left(\delta_{\mathrm{C}} 155.6\right)$ and $\mathrm{C}-2$, and from $\delta_{\mathrm{H}} 12.62$ to $\mathrm{C}-8\left(\delta_{\mathrm{C}} 158.2\right), \mathrm{C}-7 \mathrm{a}\left(\delta_{\mathrm{C}} 114.2\right)$ and $\mathrm{C}-9\left(\delta_{\mathrm{C}} 138.6\right)$, enabled assignment of these two hydroxyl groups at $\mathrm{C}-1$ and $\mathrm{C}-8$, respectively. The singlet aromatic methyl $\left(\delta_{\mathrm{H}} 2.48, \delta_{\mathrm{C}} 21.4\right)$ was confirmed at C-3 $\left(\delta_{\mathrm{C}} 142.1\right)$ by HMBC correlations from $\delta_{\mathrm{H}} 2.48$ to C-3, C-2 and C-4. The tetrangulol skeleton was further elucidated by HBMC correlations of two pairs of ortho-coupled protons at C-5, C-6, C-10 and C-11 (Figure 2). Moreover, the ${ }^{1} \mathrm{H}$ NMR spectra displayed seven proton signals between $\delta_{\mathrm{H}} 4.92$ and $\delta_{\mathrm{H}} 3.07$, consistent with seven ${ }^{13} \mathrm{C}$ signals of sp ${ }^{3}$ methines between $\delta_{\mathrm{C}} 98.9$ and 71.3. These data support the presence of a disaccharide moiety composed of $\beta$-D-olivose and $\alpha$-L-amicetose on the basis of 2D NMR correlation analyses (Figures 2 and 3), and comparisons with previously reported data $[18,19]$. COSY correlations of $\mathrm{H}-1^{\prime}\left(\delta_{\mathrm{H}} 4.90\right) / \mathrm{H}-2^{\prime} \mathrm{b}\left(\delta_{\mathrm{H}} 1.46\right), \mathrm{H}-2^{\prime} \mathrm{a}\left(\delta_{\mathrm{H}}\right.$ $2.57) / \mathrm{H}-3^{\prime}\left(\delta_{\mathrm{H}} 3.87\right) / \mathrm{H}-4^{\prime}\left(\delta_{\mathrm{H}} 3.07\right) / \mathrm{H}-5^{\prime}\left(\delta_{\mathrm{H}} 3.57\right) / \mathrm{H}-6{ }^{\prime}$ revealed the fragment of $\mathrm{C}-1^{\prime} / \mathrm{C}-2^{\prime} / \mathrm{C}-3^{\prime} / \mathrm{C}-4^{\prime} /$ $\mathrm{C}-5^{\prime} / \mathrm{C}-6^{\prime}$. The HMBC correlation of $\mathrm{H}-1^{\prime} / \mathrm{C}-5^{\prime}$ confirmed the existence of an olivose ring. The important $\mathrm{HMBC}$ correlations from the anomeric methine proton $\left(\mathrm{CH}-1^{\prime}\right)$ to $\mathrm{C}-8, \mathrm{C}-9$, and $\mathrm{C}-10$ indicated the $\mathrm{C}$-glycosidic bond $\left(\mathrm{C}-9-\mathrm{C}-1^{\prime}\right)$ between the aglycone and olivose unit. Similarly, the COSY correlations of H-1" $\left(\delta_{\mathrm{H}} 4.92\right) / \mathrm{H}-2 " \mathrm{~b}\left(\delta_{\mathrm{H}} 1.83\right) / \mathrm{H}-3$ "a $\left(\delta_{\mathrm{H}} 1.87\right) / \mathrm{H}-4$ " $\left(\delta_{\mathrm{H}} 3.36\right) / \mathrm{H}-5$ " $\left(\delta_{\mathrm{H}} 3.91\right) /$ $\mathrm{H}-6$ " $\left(\delta_{\mathrm{H}} 1.33\right)$, and the HMBC correlation of $\mathrm{H}-1 " / \mathrm{C}-5^{\prime \prime}$ disclosed the presence of a six membered deoxysugar, which was elucidated as amicetose by comparing the ${ }^{1} \mathrm{H}$ and ${ }^{13} \mathrm{C}$ NMR data with those reported [18]. Further HMBC correlations from H-1" to C-4' revealed the connection of C-1"-O-C-4' between olivose and amicetose. The relative configurations of two sugar moieties were confirmed by NOESY correlations of H-1'/H-3', H-1'/H-5', H-1"/H-4' and H-4"/CH3-6" (Figure 3).

Compound 2, named marangucycline $\mathrm{B}$, was obtained as a brown amorphous powder. The IR spectrum showed one additional ketone absorption at $1730 \mathrm{~cm}^{-1}$ and the characteristic hydroxyl group absorption at $\approx 3400 \mathrm{~cm}^{-1}$ was almost completely absent. The molecular formula $\mathrm{C}_{31} \mathrm{H}_{28} \mathrm{O}_{9}$ was determined by HR-ESI-MS, which was four mass units less than that of compound 1, indicating 18 degrees of unsaturation. Therefore, compound 2 was presumed to have one new ketone group and one additional ring relative to compound $\mathbf{1}$. The ${ }^{13} \mathrm{C}$ NMR spectrum were similar with those of $\mathbf{1}$ (Supplementary Information), except that one carbonyl signal at $\delta \mathrm{C} 207.7$ (C-4") was observed. Moreover, one of the anomeric carbone (C-1") signal was changed from $\delta_{\mathrm{C}} 98.9$ in $\mathbf{1}$ to $\delta_{\mathrm{C}} 91.4$ in 2. Comparing these characteristic data with the reported [19] revealed the presence of a cinerulose $\mathrm{B}$ unit in 2, which subsequently proved by $2 \mathrm{D}$ NMR analyses (Figure 2). COSY spectrum indicated the fragments of C-1"/C-2"/C-3" and C-5"/C-6". The HMBC correlations of CH-1"/C-5", CH $\mathrm{CH}_{2}-3^{\prime \prime} / \mathrm{C}-4 "$, and $\mathrm{CH}_{3}-6 " \mathrm{C}-5^{\prime \prime}$ confirmed the structure elucidation of cinerulose $\mathrm{B}$. The HMBC correlation from $\mathrm{CH}-1$ " to $\mathrm{C}-4^{\prime}$ revealed the C-1"-O-C-4' linkage. Meanwhile, the ${ }^{13} \mathrm{C}$ NMR resonance of C-4' shifted upfield from $\delta_{\mathrm{C}} 89.2$ in $\mathbf{1}$ to $\delta_{\mathrm{C}} 74.5$ in $\mathbf{2}$, indicating the connection of C-2"-O-C-3'. Consequently, the disaccharide in 2 was determined to be a cinerulose B-(1 $\rightarrow 4,2 \rightarrow 3)$-olivosyl unit. The NOESY correlations of $\mathrm{H}-1^{\prime} / \mathrm{H}-3^{\prime}, \mathrm{H}-1^{\prime} / \mathrm{H}-5^{\prime}, \mathrm{H}-3^{\prime} / \mathrm{H}-2^{\prime \prime}, \mathrm{H}-2^{\prime \prime} / \mathrm{H}-1^{\prime \prime}$ and $\mathrm{H}-4^{\prime} / \mathrm{H}-5^{\prime \prime}$ confirmed the relative configurations of the two sugars (Figure 3). The ${ }^{1} \mathrm{H}$ and ${ }^{13} \mathrm{C}$ NMR data for this disaccharide were consistent 
with these previously reported for compounds with $\alpha$-cinerulose B-( $1 \rightarrow 4,2 \rightarrow 3)-\beta$-olivosyl [19]. In a fashion analogous to that applied to compound 1, the skeleton of $\mathbf{2}$ was determined by comprehensive analyses of COSY, HMQC and HMBC spectra (Figures 2 and 3).

In addition to compounds 1 and 2, Streptomycetes sp. strain SCSIO 11594 was found to produce known compounds dehydroxyaquayamycin (3) [14], undecylprodigiosin (4) and metacycloprodigiosin (5) [20]. The structures were determined by comparative analyses using previously reported $\mathrm{MS},{ }^{1} \mathrm{H}$, and ${ }^{13} \mathrm{C}$ NMR data.

\subsection{Cytotoxicities and Antibacterial Activities}

The angucyclines are a large group of natural products; members are characterized by an angular tetracyclic (benz $[\alpha]$ anthracene) structure with a hydrolysable sugar moiety. Angucyclines often express a broad range of biological activities. Members of the angucyclines have been noted as potent cytotoxins, antibacterials, antivirals and as inhibitors of assorted enzymes and of platelet aggregation [17,21]. The first reported compounds of this class were tetrangomycin and tetrangulol [17]. To our knowledge, the sugar unit of these species was usually linked at the tetrangomycin C-9 with a $\mathrm{C}-\mathrm{C}$ bond and at the tetrangulol C-8 with a C-O bond. The antitubercular and cytotoxic compound dehydroxyaquayamycin (3), was the first compound shown to have a C-9 linked sugar unit using C-C connectivity with the tetrangulol skeleton. This agent was obtained as a derivative of aquayamycin [15] and later isolated as a natural product from the marine-derived Streptomyces sp. BCC45596 [14]. Compounds 1 and 2 were additions to this class of natural products; 1-3 were isolated from marine-derived Streptomyces sp. SCSIO 11594 as secondary metabolites.

Compounds 1-5 were tested for potential in vitro cytotoxicity against human lung cancer cell line A549, human nasopharyngeal carcinoma cell line CNE2, human breast adenocarcinoma cell line MCF-7, human hepatocarcinoma cancer cell line HepG2, and the normal hepatic cell line HL7702. The results were shown in Table 2 . These data indicate that compound 4 is $\approx 1$-10-fold more cytotoxic than the positive control cisplatin whereas compound 2 , with its keto-sugar moiety, is $\approx 10-20$-fold more potent than cisplatin. Interestingly, $\mathbf{2}$ and $\mathbf{4}$ demonstrate significant cytotoxic selectivity, with estimated therapeutic ratio values of 7-5 and 3-45, respectively, as reflected by comparisons of tumor cell-derived IC $_{50}$ values and those obtained using HL7702 cells (non-cancerous control). Detailed examination of the structure-activity relationship (SAR) of the cytotoxicities of compounds 1-3 revealed that (i) the presence of ketone group and $\mathrm{C}-2$ "-O-C-3' connection in the disaccharide moiety of compound 2 is critical important for the cytotoxicity; and (ii) the appearance of $\alpha$-amicetose in the disaccharide chain sharply decreased the cytotoxicity. The SAR study of compounds $\mathbf{4}$ and $\mathbf{5}$ revealed that the open form of the aliphatic side chain plays an important role for the cytotoxicity. The anticancer activity of the related natural products has been described in a number of literatures [22-24], and the structure activity relationships of related synthetic natural products have been reported [25-28].

The antibacterial activities of compounds 1-5 were evaluated using MRSE shhs-E1, methicillin-resistant Staphylococcus aureus (MRSA) shhs-A1, Staphylococcus aureus ATCC 29213, Enterococcus faecalis ATCC29212, Escherichia coli ATCC 25922, Micrococcus luteus, and multidrug resistant Pseudomonas aeruginosa. These assays revealed that 1-3 have weak antibacterial activity against Enterococcus faecalis ATCC29212 with a MIC of $64.0 \mu \mathrm{g} / \mathrm{mL}$ in all cases and that 3 is 
selective against MRSE shhs-E1 demonstrating an MIC of $16.0 \mu \mathrm{g} / \mathrm{mL}$. Compounds 4 and 5 did not show antibacterial activities against any of the above tested bacteria at a concentration up to $64.0 \mu \mathrm{g} / \mathrm{mL}$.

Table 2. Summary of in vitro cytotoxicities $\left(\mathrm{IC}_{50}\right.$ in $\left.\mu \mathrm{M}\right)$ for $\mathbf{1 - 5}$ against four human cancer cell lines and one normal hepatic cell line HL7702 $(n=3)$ and estimated therapeutic ratio (TR) values.

\begin{tabular}{ccccccc}
\hline Agent & A549 & CNE2 & MCF-7 & HepG2 & HL7702 & TR \\
\hline $\mathbf{1}$ & $>50.0$ & $>50.0$ & $>50.0$ & $>50.0$ & $>50.0$ & - \\
$\mathbf{2}$ & $0.45 \pm 0.03$ & $0.56 \pm 0.02$ & $0.24 \pm 0.003$ & $0.43 \pm 0.05$ & $3.67 \pm 0.07$ & $7-15$ \\
$\mathbf{3}$ & $16.40 \pm 0.19$ & $22.27 \pm 0.07$ & $23.65 \pm 0.09$ & $18.81 \pm 0.12$ & $49.34 \pm 0.17$ & $2-3$ \\
$\mathbf{4}$ & $0.85 \pm 0.01$ & $0.28 \pm 0.02$ & $1.11 \pm 0.07$ & $4.67 \pm 0.09$ & $12.47 \pm 0.09$ & $3-45$ \\
$\mathbf{5}$ & $>50.0$ & $>50.0$ & $>50.0$ & $>50.0$ & $>50.0$ & - \\
Cisplatin & $4.56 \pm 0.04$ & $3.75 \pm 0.03$ & $5.26 \pm 0.07$ & $4.14 \pm 0.06$ & $15.34 \pm 0.08$ & $3-4$ \\
\hline
\end{tabular}

\subsection{Identification of Strain SCSIO 11594}

Strain SCSIO 11594 (Figure 4a) was isolated from a sediment sample collected from the South China Sea $\left(115^{\circ} 27.751 \mathrm{E}, 1^{\circ} 28.581 \mathrm{~N}\right)$ at a depth of $2403 \mathrm{~m}$ using HRA medium (histidine $0.1 \mathrm{~g}$, raffinose $1.0 \mathrm{~g}, \mathrm{Na}_{2} \mathrm{HPO}_{4} 0.3 \mathrm{~g}, \mathrm{KCl} 1.7 \mathrm{~g}, \mathrm{MgSO}_{4} \cdot 7 \mathrm{H}_{2} \mathrm{O} 0.05 \mathrm{~g}, \mathrm{FeSO}_{4} \cdot 7 \mathrm{H}_{2} \mathrm{O} 0.01 \mathrm{~g}, \mathrm{CaCO}_{3} 0.02 \mathrm{~g}$, agar $12 \mathrm{~g}, \mathrm{pH} 7.2$, seawater $500 \mathrm{~mL}$, distilled water $500 \mathrm{~mL}$ ) with incubation at $28{ }^{\circ} \mathrm{C}$ for up to 4 weeks. The strain is preserved at the RNAM Center for Marine Microbiology, South China Sea Institute of Oceanology, Chinese Academy of Sciences. Extraction of genomic DNA, PCR amplification, sequencing of the 16S rRNA gene, and phylogenetic analysis were performed as described by You and co-workers [29]. The 16S rRNA gene sequence has been deposited in GenBank with accession no. KP276583. The results of phylogenetic analyses showed that strain SCSIO 11594 should be a member of the genus Streptomyces. The 16S rRNA gene sequence of strain SCSIO 11594 demonstrated the highest similarity value to Streptomyces rubrogriseus LMG $20318^{\mathrm{T}}(99.86 \%)$ and was found to cluster with members of the genus Streptomyces in the phylogenetic tree (Figure 4b).

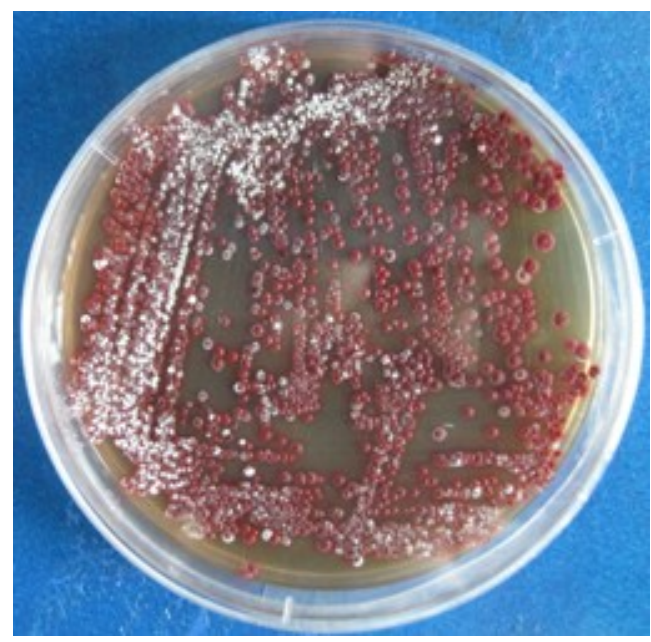

(a)

Figure 4. Cont. 


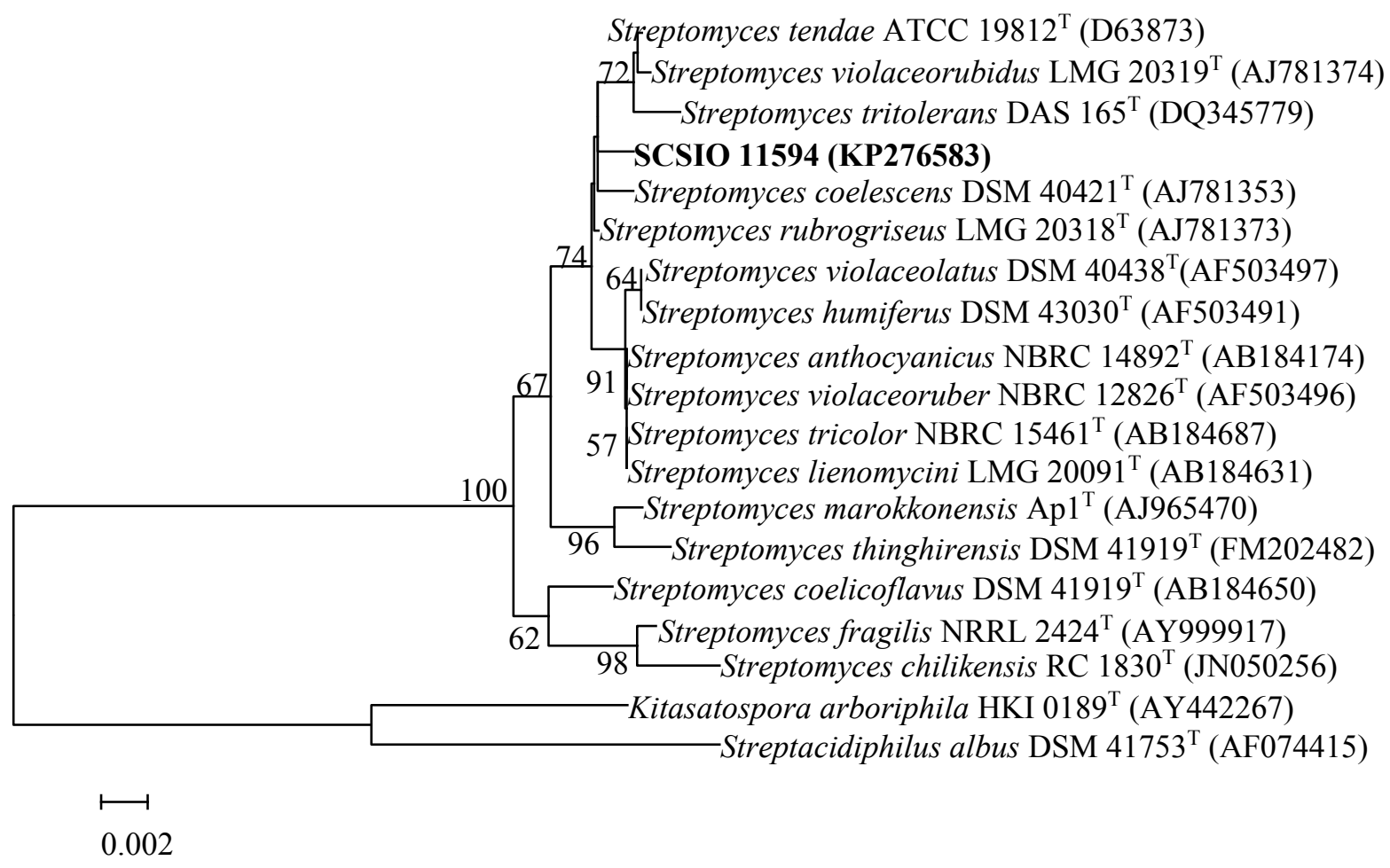

(b)

Figure 4. (a) Strain SCSIO 11594; (b) Neighbor-joining phylogenetic tree based on $16 \mathrm{~S}$ rRNA gene sequences of strain SCSIO 11594 and members of the family Streptomycetaceae. Bootstrap values (expressed as percentages of 1000 replications) exceeding 50\% are shown at the branch points.

\section{Experimental Section}

\subsection{General Experimental Procedures}

Optical rotations were determined using an MCP-500 polarimeter (Anton Paar, Graz, Austria). UV spectra were obtained with a UV-2600 spectrometer (Shimadzu, Tokyo, Japan). IR spectra were measured using an IRAffinity-1 spectrophotometer (Shimadzu, Tokyo, Japan). NMR spectra were acquired with an Avance 500 spectrometer (Bruker, Fällanden, Switzerland) at $500 \mathrm{MHz}$ for the ${ }^{1} \mathrm{H}$ nucleus and $125 \mathrm{MHz}$ for the ${ }^{13} \mathrm{C}$ nucleus. ESIMS and HRESIMS data were determined using an amaZon SL ion trap mass spectrometer and MaXis quadrupole-time-of-flight mass spectrometer (Bruker, Bremen, Germany), respectively. CC (Column chromatography) was performed on 100-200 mesh silica gel (Yantai Jiangyou Silica Gel Development Co., Ltd., Yantai, China). RP-MPLC (reversed phase-medium pressure preparative liquid chromatography) were carried out using the CHEETAH MP200 (Agela Technologies, Tianjin, China) and Claricep Flash columns filled with ODS (40-63 $\mu \mathrm{m}, \mathrm{YMC}$ ). RP-HPLC (high performance liquid chromatography) analyses were carried out using a Hitachi HPLC with YMC-Pack ODS-A column $(250 \times 10 \mathrm{~mm}, 5 \mu \mathrm{m})$. 


\subsection{Fermentation, Extraction and Isolation of the Compounds}

The strain was inoculated to a modified ISP-4 agar plate (soluble starch $1.0 \%, \mathrm{~K}_{2} \mathrm{HPO}_{4} 0.1 \%$, $\mathrm{MgSO}_{4} \cdot 7 \mathrm{H}_{2} \mathrm{O} 0.1 \%,\left(\mathrm{NH}_{4}\right)_{2} \mathrm{SO}_{4} 0.2 \%, \mathrm{CaCO}_{3} 0.2 \%$, sea salt $3.0 \%, \mathrm{pH} 7.2$ before sterilization) from a glycerol tube under aseptic conditions and incubated 5 day at $28{ }^{\circ} \mathrm{C}$. The mycelium was then transferred into $250 \mathrm{~mL}$ Erlenmeyer flasks each containing $50 \mathrm{~mL}$ of modified-AM2ab medium (soluble starch $0.5 \%$, soybean powder $0.5 \%$, yeast exact power $0.2 \%$, bacterial peptone $0.2 \%$, glucose $2.0 \%, \mathrm{KH}_{2} \mathrm{PO}_{4} 0.05 \%, \mathrm{MgSO}_{4} \cdot 7 \mathrm{H}_{2} \mathrm{O} 0.05 \%, \mathrm{NaCl} 0.40 \%$, sea salt $3.0 \% \mathrm{CaCO}_{3} 0.2 \%, \mathrm{pH} 7.2$ before sterilization) and incubated on rotary shakers with $200 \mathrm{rpm}$ at $28{ }^{\circ} \mathrm{C}$ for $36 \mathrm{~h}$. Each culture (seed) was then inoculated into $1 \mathrm{~L}$ Erlenmeyer flasks containing $200 \mathrm{~mL}$ of modified-AM2ab and fermentation continued under the conditions used to generate the seed cultures. Incubation was carried out under these conditions for 8 day. The $16 \mathrm{~L}$ of culture was then harvested and centrifuged at $3214 \times \mathrm{g}$ (3900 rpm) for $10 \mathrm{~min}$ to yield the supernatant and mycelial cake, which was extensively extracted by butanone and acetone, respectively. The extracted residues were combined after HPLC analyses to validate extract contents.

The combined residues were subjected to silica gel $\mathrm{CC}$ using gradient elution initially using petroleum ether (P)/chloroform (C) (200/0, 100/100, v/v), and then with $\mathrm{C} / \mathrm{MeOH}(\mathrm{M})(150 / 0,147 / 3$, $144 / 6,141 / 9,138 / 12,145 / 15,130 / 30,75 / 75, \mathrm{v} / \mathrm{v})$, to give ten fractions A1-A10. The fractions A4-A8 were combined and further subjected to ODS column MPLC by eluting with a linear gradient from $70 / 30 / 0.1\left(\mathrm{MeCN} / \mathrm{H}_{2} \mathrm{O} / \mathrm{HAc}\right)$ to $100 / 0 / 0.1$ over $60 \mathrm{~min}$ at $15 \mathrm{~mL} / \mathrm{min}$ with detection at $323 \mathrm{~nm}$; elution was then continued with 100/0/0.1 for $30 \mathrm{~min}$ to ultimately afford fractions B1-B9. The fractions B6 and $B 7$ and B8 and B9 were subjected to $C$ c silica gel with a gradient elution (P/C 10/40, 0/50, C/M $49.5 / 0.5,49 / 1,48.5 / 1.5, \mathrm{v} / \mathrm{v})$, respectively, to give fractions $\mathrm{C} 1-17$ and $\mathrm{D} 1-17$. The fractions $\mathrm{C} 12$ and C13 and D9-12 were repeatedly eluted by isocratic SP-HPLC elution with $\mathrm{MeCN} / \mathrm{H}_{2} \mathrm{O} / \mathrm{HAc}(95 / 5 / 0.1)$ at $2.5 \mathrm{~mL} / \mathrm{min}$ and detection at $323 \mathrm{~nm}$, respectively, to generate compound $\mathbf{1}(30.5 \mathrm{mg})$ at a retention time of $12.2 \mathrm{~min}$ and compound $2(7.5 \mathrm{mg})$ with retention time $14.3 \mathrm{~min}$. Similarly, compound 3 $(3.7 \mathrm{mg})$ was isolated from $\mathrm{B} 5$ by repeated isocratic RP-HPLC elution with $\mathrm{MeCN} / \mathrm{H}_{2} \mathrm{O} / \mathrm{HAc}$ $(85 / 15 / 0.1)$ and a retention time of $8.7 \mathrm{~min}$. Fraction A3 was subjected to silica gel CC with gradient elution (P/C 50/0, 40/10, 30/20, 20/30, 10/40, 0/50, C/M 49.5/0.5, 49/1) to afford fractions E1-E8; E5-E7 were repeatedly subjected to preparative TLC (100\% chloroform) to afford 4 (33.2 $\mathrm{mg})$ and $5(45.3 \mathrm{mg})$ with $\mathrm{R}_{\mathrm{f}}$ values of 0.7 and 0.4 , respectively.

Marangucycline $\boldsymbol{A}$ (1): brown amorphous powder; $[\alpha]^{25} \mathrm{D} 35.0\left(c 0.37, \mathrm{CHCl}_{3}\right)$; $\mathrm{UV}\left(\mathrm{CHCl}_{3}\right) \lambda_{\max }$ (log ع) 239 (4.39), 323 (4.31), 437 (3.87) nm; IR (ATR) v $v_{\max }$ 3418, 2928, 2878, 1631, 1269, $1049 \mathrm{~cm}^{-1}$; ${ }^{1} \mathrm{H}$ and ${ }^{13} \mathrm{C}$ NMR spectroscopic data, Table $1 ;(-)$-ESIMS $m / z[\mathrm{M}-\mathrm{H}]^{-}$547.42, and $(+)$-HRESIMS $m / z[\mathrm{M}+\mathrm{Na}]^{+}$571.1946, calcd for $\mathrm{C}_{31} \mathrm{H}_{32} \mathrm{O}_{9} \mathrm{Na}, 571.1939$.

Marangucycline B (2): brown amorphous powder; $[\alpha]^{25} \mathrm{D} 30.5\left(c 0.19, \mathrm{CHCl}_{3}\right)$; $\mathrm{UV}\left(\mathrm{CHCl}_{3}\right) \lambda_{\max }$ (log ع) 239 (4.15), 323 (4.03), 436 (3.58) nm; IR (ATR) $v_{\max }$ 2922, 2852, 1730, 1635, 1254, 1109, $1069 \mathrm{~cm}^{-1} ;{ }^{1} \mathrm{H}$ and ${ }^{13} \mathrm{C}$ NMR spectroscopic data, Table 1; (+)-HRESIMS $m / z[\mathrm{M}+\mathrm{H}]^{+}$545.1796, calcd for $\mathrm{C}_{31} \mathrm{H}_{29} \mathrm{O}_{9}, 545.1806$; [M $\left.+\mathrm{Na}\right]^{+}$567.1620, cacld for $\mathrm{C}_{31} \mathrm{H}_{28} \mathrm{O} 9 \mathrm{Na}, 567.1626$. 


\subsection{Cytotoxicity Assays}

Compounds 1-5 were evaluated for cytotoxic activity using four human cancer cell lines, A549, CNE2, HepG2, MCF-7, one normal hepatic cell line HL7702 and previously reported MTT methodologies [30]. IC 50 values were calculated using GraphPad Prism 5 software. All data were obtained in triplicate and are presented as means \pm SD. Cisplatin was used as a positive control.

\subsection{Antibacterial Activities Assay}

The antibacterial activities of compounds 1-5 were assessed using seven strains of pathogenic bacteria including MRSE shhs-E1, MRSA shhs-A1, Staphylococcus aureus ATCC 29213, Enterococcus faecalis ATCC29212, Escherichia coli ATCC 25922, Micrococcus luteus, and multidrug resistant Pseudomonas aeruginosa. Dilution antimicrobial susceptibility tests for aerobic bacteria were carried out as previously reported [31,32]. Lowest concentrations of antimicrobial agents that completely inhibit cell growth in microdilution wells were determined by naked eye.

\section{Conclusions}

Five compounds including two new angucycline antibiotics, marangucycline A (1) and marangucycline B (2), were isolated from the deep-sea derived Streptomyces sp. SCSIO11594. Compounds 2 and 4, especially the new C-glycoside angucycline compound 2, displayed in vitro cytotoxicities against four cancer cell lines A594, CNE2, HepG2, MCF-7 superior to those noted with cisplatin. Remarkably, compounds $\mathbf{2}$ and $\mathbf{4}$ demonstrated significant anti-tumor selectivity. These data enable important correlations of structure to biological function and may be important for future drug lead efforts. Additionally, dehydroxyaquayamycin (3) was found to exert selective antibacterial activity against MRSE shhs-E1. This realization may prove important during the course of structure-activity relationship studies aimed at new antibacterial drug discovery/design studies.

\section{Acknowledgments}

This study was supported, in part, by the National Natural Science Foundation of China (41206135, 41476133, and 81425022), Talents Recruitment Grant of "Yangfan Plan" of Guangdong Province, China (YueRenCaiBan (2014) 1), the National High Technology Research and Development Program of China (2012AA092104), and a special financial fund for innovative developments of the Marine Economic Demonstration Project (GD2012-D01-001 and GD2012-D01-002). Additionally, we thank the analytical facility center of the South China Sea Institute of Oceanology, Xiao, and Li for recording NMR data and Sun, and Zhang for acquiring ESIMS and HRESIMS data.

\section{Author Contributions}

Y.S. performed the fermentation and isolation of the compounds and wrote the paper. G.L. tested the biological activities. J.L. isolated and identified the strain Streptomyces sp. SCSIO11594. H.H. and X.Z. elucidated the compound structures. H.Z. and J.J. designed the study, analyzed results and wrote the paper. 


\section{Conflicts of Interest}

The authors declare no conflict of interest.

\section{References}

1. Xiong, Z.Q.; Wang, J.F.; Hao, Y.Y.; Wang, Y. Recent advances in the discovery and development of marine microbial natural products. Mar. Drugs 2013, 11, 700-717.

2. Eom, S.H.; Kim, Y.M.; Kim, S.K. Marine bacteria: Potential sources for compounds to overcome antibiotic resistance. Appl. Microbiol. Biotechnol. 2013, 97, 4763-4773.

3. Cheung, R.C.; Wong, J.H.; Pan, W.L.; Chan, Y.S.; Yin, C.M.; Dan, X.L.; Wang, H.X.; Fang, E.F.; Lam, S.K.; Ngai, P.H.; et al. Antifungal and antiviral products of marine organisms. Appl. Microbiol. Biotechnol. 2014, 98, 3475-3494.

4. Skropeta, D. Deep-sea natural products. Nat. Prod. Rep. 2008, 25, 1131-1166.

5. Skropeta, D.; Wei, L. Recent advances in deep-sea natural products. Nat. Prod. Rep. 2014, 31, 999-1025.

6. Berdy, J. Bioactive microbial metabolites. J. Antibiot. 2005, 58, 1-26.

7. Lam, K.S. Discovery of novel metabolites from marine actinomycetes. Curr. Opin. Microbiol. 2006, 9, 245-251.

8. Zotchev, S.B. Marine actinomycetes as an emerging resource for the drug development pipelines. J. Biotechnol. 2012, 158, 168-175.

9. Subramani, R.; Aalbersberg, W. Marine actinomycetes: An ongoing source of novel bioactive metabolites. Microbiol. Res. 2012, 167, 571-580.

10. Zhou, X.; Huang, H.; Chen, Y.; Tan, J.; Song, Y.; Zou, J.; Tian, X.; Hua, Y.; Ju, J. Marthiapeptide A, an anti-infective and cytotoxic polythiazole cyclopeptide from a $60 \mathrm{~L}$ scale fermentation of the deep sea-derived Marinactinospora thermotolerans SCSIO 00652. J. Nat. Prod. 2012, 75, 2251-2255.

11. Huang, H.; Yao, Y.; He, Z.; Yang, T.; Ma, J.; Tian, X.; Li, Y.; Huang, C.; Chen, X.; Li, W.; et al. Antimalarial $\beta$-carboline and indolactam alkaloids from Marinactinospora thermotolerans, a deep sea isolate. J. Nat. Prod. 2011, 74, 2122-2127.

12. Song, Y.; Li, Q.; Liu, X.; Chen, Y.C.; Zhang, Y.; Sun, A.; Zhang, W.; Zhang, J.; Ju, J. Cyclic hexapeptides from the deep South China Sea-derived Streptomyces scopuliridis SCSIO ZJ46 active against pathogenic Gram-positive Bacteria. J. Nat. Prod. 2014, 77, 1937-1941.

13. Zhou, X.; Huang, H.; Li, J.; Song, Y.; Jiang, R.; Liu, J.; Zhang, S.; Hua, Y.; Ju, J. New anti-infective cycloheptadepsipeptide congeners and absolute stereochemistry from the deep sea-derived Streptomyces drozdowiczii SCSIO 10141. Tetrahedron 2014, 70, 7795-7801.

14. Supong, K.; Thawai, C.; Suwanborirux, K.; Choowong, W.; Supothina, S.; Pittayakhajonwut, P. Antimalarial and antitubercular C-glycosylated benz $[\alpha]$ anthraquinones from the marine-derived Streptomyces sp. BCC45596. Phytochem. Lett. 2012, 5, 651-656.

15. Sezaki, M.; Kondo, S.; Maeda, K.; Umezawa, H.; Ono, M. The structure of aquayamycin. Tetrahedron 1970, 26, 5171-5190. 
16. Kuntsmann, M.P.; Mitscher, L.A. The structural characterization of tetrangomycin and tetrangulol. J. Org. Chem. 1966, 31, 2920-2925.

17. Rohr, J.; Thiericke, R. Angucycline group antibiotics. Nat. Prod. Rep. 1992, 9, 103-137.

18. Oki, T.; Kitamura, I.; Matsuzawa, Y.; Shibamoto, N.; Ogasawara, T.; Yoshimoto, A.; Inui, T.; Naganawa, H.; Takeuchi, T.; Umezawa, H. Anti-tumor anthracycline antibiotics, aclacinomycin-A and analogs. 2. structural determination. J. Antibiot. 1979, 32, 801-819.

19. Huang, H.; Yang, T.; Ren, X.; Liu, J.; Song, Y.; Sun, A.; Ma, J.; Wang, B.; Zhang, Y.; Huang, C.; et al. Cytotoxic angucycline class glycosides from the deep sea actinomycete Streptomyces lusitanus SCSIO LR32. J. Nat. Prod. 2012, 75, 202-208.

20. Liu, R.; Cui, C.B.; Duan, L.; Gu, Q.Q.; Zhu, W.M. Potent in vitro anticancer activity of metacycloprodigiosin and undecylprodigiosin from a sponge-derived actinomycete Saccharopolyspora sp. nov. Arch. Pharm. Res. 2005, 28, 1341-1344.

21. Abdelfattah, M.S.; Kharel, M.K.; Hitron, J.A.; Baig, I.; Rohr, J. Moromycins A and B, isolation and structure elucidation of C-glycosylangucycline-type antibiotics from Streptomyces sp. KY002. J. Nat. Prod. 2008, 71, 1569-1573.

22. Omura, S.; Tanaka, H.; Oiwa, R.; Awaya, J.; Masuma, R.; Tanaka, K. New antitumor antibiotics, OS-4742 A1, A2, B1 and B2 produced by a strain of Streptomyces. J. Antibiot. 1977, 30, 908-916.

23. Imamura, N.; Kakinuma, K.; Ikekawa, N.; Tanaka, H.; Omura, S. The structure of vineomycin B2. J. Antibiot. 1981, 34, 1517-1518.

24. Imamura, N.; Kakinuma, K.; Ikekawa, N.; Tanaka, H.; Omura, S. Biosynthesis of vineomycins A1 and B2. J. Antibiot. 1982, 35, 602-608.

25. Morton, G.E.; Barrett, A.G.M. Iterative benzyne-furan cycloaddition reactions: Studies toward the total synthesis of ent-Sch 47554 and ent-Sch 47555. Org. Lett. 2006, 8, 2859-2861.

26. Sobti, A.; Kim, K.J.; Sulikowski, G.A. Application of glycosyltetrazoles in oligosaccharide synthesis: Assembly of the C3 trisaccharide component of the antibiotic PI-080. J. Org. Chem. 1996, 61, 6-7.

27. Yu, X.; O'Doherty, G.A. De novo asymmetric synthesis and biological evaluation of the trisaccharide portion of PI-080 and vineomycin B2. Org. Lett. 2008, 10, 4529-4532.

28. Yu, X.M.; Li, M.S.; O'doherty, G.A. De novo asymmetric approach to the disaccharide portion of Sch-47554. Heterocycles 2011, 82, 1577-1584.

29. You, Z.Q.; Li, J.; Qin, S.; Tian, X.P.; Wang, F.Z.; Zhang, S. Georgenia sediminis sp. nov. a moderately thermophilic actinobacterium isolated from sediment. Int. J. Syst. Evol. Microbiol. 2013, 63, 4243-4247.

30. Mosmann, T. Rapid colorimetric assay for cellular growth and survival: Application to proliferation and cytotoxicity assays. J. Immunol. Methods 1983, 65, 55-63.

31. CLSI. Methods for Dilution Antimicrobial Susceptibility Tests for Bacteria That Grow Aerobically, Approved Standard-8th ed.; Clinical and Laboratory Standards Institute: Wayne, PA, USA, 2009; pp. M07-A8. 
32. Song, Y.; Huang, H.; Chen, Y.; Ding, J.; Zhang, Y.; Sun, A.; Zhang, W.; Ju, J. Cytotoxic and antibacterial marfuraquinocins from the deep South China Sea-derived Streptomyces niveus SCSIO 3406. J. Nat. Prod. 2013, 76, 2263-2268.

(C) 2015 by the authors; licensee MDPI, Basel, Switzerland. This article is an open access article distributed under the terms and conditions of the Creative Commons Attribution license (http://creativecommons.org/licenses/by/4.0/). 